\title{
The decrease in polyamine levels is not associated with growth inhibition in suspension-cultured rice cells under nitrogen deficiency
}

\author{
H.-I. SUNG, L.-F. LIU and C. H. KAO \\ Department of Agronomy, National Taiwan University, Taipei, Taiwan, Republic of China
}

\begin{abstract}
The effects of nitrogen deficiency on the growth and polyamine levels of suspensioncultured rice cells were investigated. Nitrogen deficiency markedly inhibited cell growth and resulted in lower levels of putrescine, spermidine and spermine than in the control culture supplied with nitrogen. The growth inhibition of rice cells induced by nitrogen deficiency could be recovered by the addition of a mixture of amino acids (glycine, L-aspartic acid, L-glutamic acid and L-arginine), but not by polyamines (putrescine, spermidine or spermine). Our results indicate that the decline of polyamine levels is not a factor causing growth inhibition of suspension-cultured rice cells under nitrogen deficiency.
\end{abstract}

Key words: arginine, aspartic acid, glycine, glutamic acid, Oryza sativa, putrescine, spermidine, spermine

\section{Introduction}

The polyamines occur ubiquitously in plants, animals, and prokaryotes, and their role in growth, development and stress metabolism has received active investigation (Evans and Malmberg 1989). In both animal cells and bacteria, changes in polyamine concentration have been shown to accompany growth (Cohen et al. 1984, Herbst and Snell 1948, Tabor et al. 1982). Polyamine levels and plant growth rates have been positively correlated in a wide variety of conditions when high levels of polyamines are associated with rapidly growing tissues (Bagni and Serafini Fracassini 1974, Evans and Malmberg 1989). Bagni et al. (1978) demonstrated that Put had the ability to substitute for inorganic nitrogen for the growth of explants from dormant tubers of Helianthus tuberosus. Bayley et al. (1972) tested Put for its ability to alleviate the reduced nitrogen requirement of soybean cells, grown in suspension culture on

Received 31 May 1994, accepted 9 August 1994

Abbreviations: Put - putrescine; SCV - Settled cell volume; Spd - spermidine; Spm - spermine.

Acknowledgement: Financial support from the National Science Council, the Republic of China is gratefully acknowledged. 
H.-I. SUNG et al.

nitrate medium. They found that Put supported growth, although less effectively than $\mathrm{NH}_{4}{ }^{+}$and glutamine.

The present investigation was designed to examine the role of polyamines in suspension-cultured rice cells under nitrogen deficiency. We present data showing that polyamine levels are not associated with growth inhibition in suspensioncultured rice cells.

\section{Materials and methods}

Rice (Oryza sativa L. cv. Tainan 5) suspension cultures were initiated from immature embryo derived calli ( $\mathrm{Yu}$ et al. 1991). The rice grain was sterilized with $1 \%$ sodium hypochlorite and one drop of Tween 20 for 20 - $30 \mathrm{~min}$ and then washed extensively with distilled water. The embryo was excised and then placed with scutellum side up on MS agar medium (Murashige and Skoog 1962) containing $0.8 \%$ agar $(\mathrm{m} / \mathrm{v}), 3 \%$ sucrose and $5 \mu \mathrm{M}$ 2,4-D (2,4-dichlorophenoxyacetic acid). The $\mathrm{pH}$ of the medium was adjusted to 5.8 before autoclaving. The embryo culture was incubated at $25{ }^{\circ} \mathrm{C}$ under white light $42 \mu \mathrm{mol} \mathrm{m} \mathrm{m}^{-2} \mathrm{~s}^{-1}$. Four weeks later, initiated calli were transferred to liquid MS medium containing $3 \%$ sucrose and $5 \mu \mathrm{M}$ 2,4-D. Approximately $500 \mathrm{mg}$ fresh mass of calli were cultured in $30 \mathrm{~cm}^{3}$ of medium in a $125-\mathrm{cm}^{3}$ Erlenmyer flask. The suspension culture was shaken on a reciprocal shaker at $120 \mathrm{rpm}$ and incubated at $25^{\circ} \mathrm{C}$ under constant irradiance of $42 \mu \mathrm{mol} \mathrm{m}^{-2} \mathrm{~s}^{-1}$. Established suspension -cultured cells were subcultured every $7 \mathrm{~d}$ by transferring about $0.5 \mathrm{~cm}^{3}$ of cells into $30 \mathrm{~cm}^{3}$ of fresh liquid MS medium in a $125-\mathrm{cm}^{3}$ flask. The cell cultures were maintained growing logarithmically and 7-d-old cultures were used for initiation all the indicated experiments.

For all experiments, about $0.8-1 \mathrm{~cm}^{3}$ of cells was transferred into $30 \mathrm{~cm}^{3}$ of tested medium in a $125-\mathrm{cm}^{3}$ flask with a graduated side-armed tube $\left(3 \mathrm{~cm}^{3}\right)$. To cause nitrogen deficiency, rice cells were cultured in the absence of inorganic nitrogen source. Polyamines and amino acids were filter sterilized before adding to the culture medium.

Suspension-cultured cells were collected by filtration through a 400 -mesh nylon sieve, and blot-dried on paper towels. The growth of rice cells was measured by settled cell volume (SCV). For SCV measurement, the time of standing of the measured suspension was $10 \mathrm{~min}$. For polyamine determination, the collected cells (about $50 \mathrm{mg}$ fresh mass) were homogenized in $5 \mathrm{~cm}^{3}$ of $5 \%$ perchloric acid. Polyamine levels were determined using high performance liquid chromatography after benzoylation as described previously (Chen and Kao 1991).

For all measurements, each treatment was repeated four times. All experiments described here were repeated three times. Similar results and identical trends obtained each time. The data reported here are from a single experiment. 


\section{Results and discussion}

Nitrogen deficiency markedly inhibited the growth of suspension-cultured rice cells (Fig. 1). The growth of rice cells with sufficient supply of nitrogen increased linearly with increasing duration of culture. However, only slight growth was observed in rice cells under nitrogen deficiency.
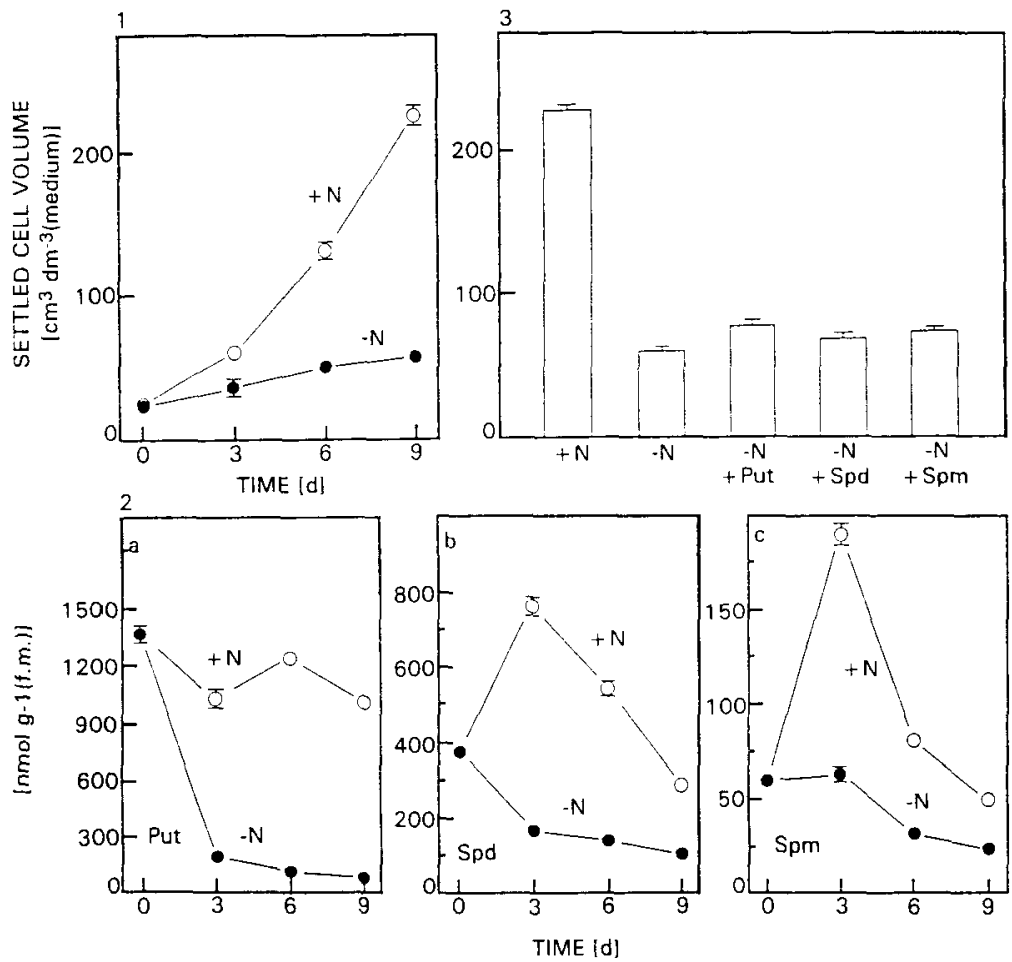

Fig. 1. Changes in the growth of rice cells cultured with sufficient nitrogen $(+N)$ and under nitrogen deficiency $(-N)$. Bars indicate standard errors $(n=4)$. Only those standard errors larger symbol size are shown.

Fig. 2. Changes in levels of polyamines in rice cells cultured with sufficient nitrogen $(+N)$ and under nitrogen deficiency $(-\mathrm{N})$. See Fig. 1 for details.

Fig. 3. Effects of polyamines on the growth of rice cells inhibited by nitrogen deficiency. The concentration of polyamines was $5 \mathrm{mM}$. The growth of rice cells was determined after $9 \mathrm{~d}$ of treatment. SCV at the start of the experiment was $33.3 \mathrm{~cm}^{3} \mathrm{dm}^{-3}$ (medium). See Fig. 1 for details.

To characterize the role of polyamines in the growth of rice cells under nitrogen deficiency, we determined the levels of polyamines in the cells cultured in the presence and absence of nitrogen. The chromatographic analysis indicated the presence of Put, Spd and Spm in suspension-cultured rice cells. Neither cadaverine nor diaminopropane was observed in rice cells. The level of Put in the control cells (supplied with sufficient nitrogen) decreased at day 3 but increased between days 6 and 9 (Fig.2). Nitrogen-deficient rice cells had much lower level of Put than the 
control cells. The levels of Spd and Spm in control cells increased at day 3 and subsequently declined (Fig. 2). Nitrogen deficiency also resulted in lower levels of Spd and Spm than the control cells. Altman and Levin (1993) demonstrated that Put and Spm levels but not Spd level in tobacco cells decreased markedly under nitrogen deficiency.

If the lower levels of polyamines are responsible for the growth inhibition in rice cells under nitrogen deficiency, then nitrogen-deficient cells are expected to recover the growth by the addition of polyamines. However, no such recovery was observed by the addition of Spd and Spm (Fig. 3). Only slight recovery was observed by the addition of Put (Fig. 3).

Table 1. Effects of the addition of amino acid mixture on cell growth and polyamine levels under nitrogen deficiency. Amino acid mixture contained glycine, L-glutamic acid, L-aspartic acid and L-arginine (each $5 \mathrm{mM}$ ). SCV and polyamines level were determined after $6 \mathrm{~d}$ of treatment. SCV at the start of the experiment was $33.3 \mathrm{~cm}^{3} \mathrm{dm}^{-3}$ (medium). Means \pm S.E. $(\mathrm{n}=4)$.

\begin{tabular}{lrlrl}
\hline Treatment & $\begin{array}{l}\mathrm{SCV} \\
{\left[\mathrm{cm}^{3} \mathrm{dm}^{-3} \text { (medium) }\right]}\end{array}$ & \multicolumn{1}{l}{$\begin{array}{l}\text { Polyamines } \\
{\left[\mathrm{nmol} \mathrm{g} \mathrm{g}^{-1}\right]}\end{array}$} & & \\
& & Put & \multicolumn{1}{c}{ Spd } & Spm \\
\hline Control & $19] \pm 4$ & $1237 \pm 18$ & $500 \pm 8$ & $65 \pm 3$ \\
$-\mathrm{N}$ & $52 \pm 2$ & $112 \pm 27$ & $125 \pm 1$ & $37 \pm 2$ \\
$-\mathrm{N}+$ Amino acid mixture & $176 \pm 4$ & $380 \pm 63$ & $78 \pm 8$ & $18 \pm 4$ \\
\hline
\end{tabular}

Addition of a mixture of amino acids, which contains glycine, L-aspartic acid, L-glutamic acid and L-arginine (each $5 \mathrm{mM}$ ), to culture medium without inorganic nitrogen source, almost complete recovery of cell growth was observed when compared with the growth of the control cells (Table 1). However, rice cells cultured in the presence of a mixture of amino acids had much lower levels of polyamine levels than the control cells (Table 1). Thus, we conclude that the decrease in polyamine levels is not associated with the growth inhibition induced by nitrogen deficiency, but is part of the overall expression of nitrogen starvation in rice cells. Our results are inconsistent with those of Bagni et al. (1978), who demonstrated that polyamine could be used as sole nitrogen sources for the in vitro growth of explants from dormant tubers of Helianthus tuberosus. Our results showed that lack of amino acids is probably the main reason causing the growth inhibition of rice cells under nitrogen deficiency.

\section{References}

Altman, A., Levin. N.: Interaction of polyamines and nitrogen nutrition in plants. - Physiol. Plant. 89 653-658, 1993.

Bagni, N.. Serafini Fracassini, D.: The role of polyamines as growth factors in higher plants and their mechanism of action. - In: Plant Growth Substances 1973. Pp. 1205-1217. Hirokawa Publishing Co., Tokyo 1974. 
Bagni, N., Calzoni, G.L., Speranza, A.: Polyamines as sole nitrogen sources for Helianthus tuberosus explants in vitro. - New Phytol. 80: 317-323, 1978.

Bayley, J.M., King, J., Gamborg, O.L.: The ability of amino compounds and conditioned medium to alleviate the reduced nitrogen requirement of soybean cells grown in suspension cultures. - Planta 105: 25-32, 1972.

Chen, C.T., Kao, C.H.: Senescence of rice leaves XXX. Levels of endogenous polyamines and darkinduced senescence of rice leaves. - Plant Cell Physiol. 32: 935-941, 1991.

Cohen, E., Arad, S.M., Heimer, Y H., Mizrahi, Y.: Polyamine biosynthetic enzymes in the cell cycle of Chlorella. - Plant Physiol. 74: 385-388, 1984.

Evans, P.T., Malmberg, R.L.: Do polyamines have roles in plant development? - Annu. Rev. Plant Physiol. Plant mol. Biol. 40: 235-269, 1989.

Herbst, E.J., Snell, E.E.: Putrescine as growth factor for Haemoplilus influenzae. - J. biol. Chem. 176: $986-990,1948$.

Murashige, T., Skoog, F.: A revised medium for rapid growth and bio-assays with tobacco tissue culture. - Physiol. Plant. 15: 473-497, 1962.

Tabor, C.W., Tabor, H., Tyagi, A.K., Cohn, M.S.: The biochemistry, genetics and regulation of polyamine biosynthesis in Saccharomyces cerevisae. - Fed. Proc. 41: 3084-3088, 1982.

Yu, S.-M., Kuo, Y.-H., Sheu, G., Sheu, T.-J., Liu, L.-F.: Metabolic derepression in suspensioncultured cells of rice. - J. biol. Chem. 266: 21131-21137, 1991. 